Diklabio: Jurnal Pendidikan dan Pembelajaran Biologi 3(1): 116-(Mei 2019) e-ISSN 2598-9669

\title{
MODEL KOOPERATIF TIPE THINK PAIR SHARE (TPS) UNTUK MENINGKATKAN KEMAMPUAN BERPIKIR KELAS X IPA 3 SMA NEGERI 1 KOTA BENGKULU
}

\author{
Muhammad Reza Arrosid ${ }^{1 *}$, Yennita ${ }^{1}$, dan Bhakti Karyadi ${ }^{1}$ \\ ${ }^{1}$ Program Studi Pendidikan Biologi, Fakultas Keguruan dan Ilmu Pendidikan, Universitas Bengkulu \\ Email :Rezaarrosidsip@Gmail.com
}

\begin{abstract}
Abstrak
Penelitian ini bertujuan untuk mendeskripsikan aktivitas siswa dan meningkatkan kemampuan berpikir kritis peserta didik melalui model kooperatif tipe think pair share (TPS). Jenis penelitian yang digunakan adalah Penelitian Tindakan Kelas dengan metode deskriptif. Penelitian dilakukan dalam dua siklus, setiap siklus terdiri dari 4 tahap yaitu perencanaan, pelaksanaan, pengamatan, dan refleksi. Instrumen yang digunakan adalah lembar observasi yang digunakan untuk mengetahui aktivitas guru dan siswa, serta lembar tes untuk mengukur kemampuan berpikir kritis siswa. Hasil analisis data observasi aktivitas guru siklus I diperoleh skor rata-rata 24,5 (baik) dan siklus II meningkat menjadi 27 (baik). Untuk hasil analisis data observasi aktivitas siswa juga mengalami peningkatan dari siklus I diperoleh skor 24,5 (baik), meningkat menjadi 27 (baik). Peningkatan aktivitas guru dan aktivitas siswa diikuti pula oleh peningkatan kemampuan berpikir kritis siswa pada materi perubahan dan pelestarian lingkungan dari siklus I ke siklus II. Pada siklus I kemampuan berpikir kritis siswa memperoleh persentase klasikal 56,43\% dengan kriteria cukup kritis, meningkat di siklus II menjadi 72,50\% dengan kriteria kritis. Berdasarkan hasil penelitian dapat disimpulkan bahwa dengan penerapan model Think pair share dapat meningkatkan aktivitas guru, aktivitas siswa dan kemampuan berpikir kritis siswa kelas X IPA3 SMAN 1 Kota Bengkulu.
\end{abstract}

Kata Kunci: think pair share, kemampuan berpikir kritis siswa, model kooperatif

\begin{abstract}
This study aims to describe the activities of students as well as to improve the critical thinking skills of learners through the application of the model of cooperative type think pair share (TPS). The type of research used in this research is Classroom Action Research with descriptive method. The study was conducted in two cycles, each cycle was derived from the four stages of planning, implementation, observation, and reflection. The research instrument used is an observation sheet used to find out the activities of teachers and students, as well as test sheets to measure students' critical thinking skills. The results of data analysis of teacher activity observation cycle I obtained an average score of 24.5 (Criteria good) and cycle II increased to 27 (good criteria). For the results of data analysis of student activity observation also increased from cycle I obtained score 24,5 (good criterion), increased to 27 (good criterion). Increased teacher activity and student activity followed by the improvement of students' critical thinking skills on materials change and environmental conservation from cycle I to cycle II. In the first cycle of critical thinking ability of students acquire a classical percentage of $56.43 \%$ with criteria quite critical, increased cycle II to 72.50\% with critical criteria. Based on the research results can be concluded that with the application of Think Pair Share model can increase teacher activity, student activity and critical thinking ability of students class X IPA ${ }_{3}$ SMAN 1 Kota Bengkulu.
\end{abstract}

Keywords: Think pair share, Critical Think, Cooperative Model 


\section{PENDAHULUAN}

Penyelenggaraan

kegiatan

pembelajaran tidak terlepas dari kurikulum. Undang-undang Nomor 20 Tahun 2003 tentang Sistem Pendidikan Nasional menyebutkan bahwa "kurikulum adalah seperangkat rencana dan pengaturan mengenai tujuan, isi, dan bahan pelajaran serta cara yang digunakan sebagai pedoman penyelenggaraan kegiatan pembelajaran untuk mencapai tujuan pendidikan tertentu". Berdasarkan definisi tersebut dapat dipahami bahwa kurikulum menempati posisi yang vital dalam penyelenggaraan pembelajaran yaitu sebagai pedoman untuk mencapai tujuan pendidikan.

Kurikulum 2013 merupakan salah satu bentuk perubahan yang dilakukan oleh pemerintah untuk mengikuti perkembangan dan mempersiapkan tuntutan pendidikan di abad 21. Salah satu karakteristik kurikulum 2013 ialah digunakannya pendekatan saintifik dalam kegiatan pembelajaran yang meliputi kegiatan Mengamati-MenanyaMengeksplorasi- Mengasosiasikan$\begin{array}{lll}\text { Mengomunikasikan (5M). Dalam } & \end{array}$ mempersiapkan pendidikan abad 21, kurikulum 2013 mengalami perkembangan yaitu pada kurikulum revisi 2017 terjadi beberapa perbaikan yaitu: 1. Mengintegrasikan Penguatan Pendidikan Karakter (PPK) didalam pembelajaran. Karakter yang diperkuat terutama 5 karakter, yaitu: religius, nasionalis, mandiri, gotong royong, dan integritas; 2. Mengintegrasikan literasi; keterampilan abad 21 atau diistilahkan dengan $4 \mathrm{C}$ (Creative, Critical thinking, Communicative, dan Collaborative); 3. Mengintegrasikan HOTS (Higher Order Thinking Skill) Brookhart (2010) dalam Arifin (2017).

Berdasarkan hasil wawancara dengan guru biologi kelas X IPA3 SMA Negeri 1 Kota Bengkulu, persentase siswa yang memiliki kemampuan berpikir kritis di kelas pada mata pelajaran biologi secara klasikal diperkirakan baru mencapai 57\% atau 16 dari 28 peserta didik, dilihat dari jumlah peserta didik yang mampu mengerjakan soal dengan kata operasional "mengapa" pada soal yang diberikan oleh guru. Hal tersebut disebabkan dalam proses pembelajaran, kemampuan berpikir kritis belum dikembangkan secara optimal meskipun guru telah menggunakan metode dan media yang disesuaikan dengan materi. Di sisi lain guru juga menyadari bahwa pembelajaran yang dikembangkan belum secara utuh menunjang kemampuan colaborative yang dapat mendorong siswa untuk berpikir secara kritis seperti tuntutan kurikulum 2013.

Menurut Mc Murarry et al (1991) dalam Muhfahroyin (2009), berpikir kritis merupakan kegiatan yang sangat penting untuk dikembangkan. Oleh sebab itu guru diharapkan mampu mengaktifkan serta mengembangkan kemampuan berpikir kritis siswa melalui proses pembelajaran.

Kemampuan berpikir kritis siswa diharapkan dapat meningkat jika siswa mampu mengkonstruksi atau membangun pengetahuan bersama melalui pemahaman yang mendalam. Proses pembelajaran harus mampu melibatkan siswa untuk berpartisipasi aktif, bukan hanya mentransfer pengetahuan dari guru ke siswa saja. Salah satu proses pembelajaran yang menunjang kemampuan kolaboratif yang dapat mengembangkan kemampuan berpikir kritis siswa adalah model pembelajaran kooperatif tipe think pair share.

Kegiatan pembelajaran dengan model kooperatif tipe think pair share terdiri dari tahap thinking (berpikir), pairing (berpasangan), dan sharing (berbagi), (Boleng, 2014). Menurut Rusmaryanti ( 2013 ) dalam Nur 'aini (2016) Prosedur yang digunakan dalam model 
Think pair share dapat memberi siswa lebih banyak waktu berpikir, merespon dan saling membantu satu sama lain sehingga dapat menciptakan pembelajaran di mana siswa aktif untuk mencari dan mengkonstruksi pengetahuan-nya bersama. Menurut Trianto (2007), model pembelajaran Think pair share (TPS) adalah model pembelajaran kooperatif yang efektif untuk membuat variasi suasana pola diskusi, model berpikir berpasangan dapat memberi siswa lebih banyak waktu berpikir, responsif dan saling membantu.

\section{METODE}

Penelitian dilaksanakan pada semester genap tahun ajaran 2017/2018 di SMAN 1 Kota Bengkulu. Peran peneliti dalam penelitian ini adalah sebagai guru biologi yang mengajar siswa pada materi Perubahan Dan Pelestarian Lingkungan. Guru dibantu oleh 2 orang observer yang mengobservasi aktivitas siswa dalam kegiatan pembelajaran dengan model kooperatif tipe think pair share. Subjek penelitian yaitu siswa kelas X IPA 3 berjumlah 28 siswa yang terdiri dari 12 siswa perempuan dan 16 siswa laki-laki.

Teknik pengumpulan data dalam penelitian ini adalah observasi dan tes. Instrumen yang digunakan berupa lembar observasi aktivitas siswa dan lembar tes kemampuan berpikir kritis. Lembar observasi aktivitas siswa digunakan untuk mengobservasi aktivitas siswa dalam kegiatan pembelajaran dengan model kooperatif tipe think pair share. Lembar kemampuan berpikir kritis terdiri dari soalsoal essay yang digunakan untuk mengukur kemampuan berpikir kritis siswa. Soal-soal essay pada lembar tes dirumuskan berdasarkan indikator kemampuan berpikir kritis, yaitu mengidentifikasi dengan memberikan penjelasan lanjutan, menganalisis dengan mengonstruksi argumen, dan merumuskan solusi alternatif (Ennis, 1985 dalam Muhfahroyin, 2009).

Data hasil observasi aktivitas siswa dianalisis dengan rerata skor dan kategori rerata skor. Kategori rerata skor aktivitas siswa terdiri dari 3 kategori, yaitu Baik, Cukup, dan Kurang. Kisaran skor untuk tiap kategori ditentukan dengan rumus berikut: Kisaran skor $=\frac{X_{n}-X_{1}}{k}$

(Susanti, 2010)

Keterangan:

$X_{n}=$ Skor maksimum

$X_{1}=$ Skor minimum

$k=$ Jumlah kategori

Kisaran skor observasi aktivitas siswa selanjutnya dikategorikan berdasarkan Tabel 1.

Tabel 1. Kategori Rerata Skor Aktivitas Siswa

\begin{tabular}{cc}
\hline Rerata Skor & Kategori \\
\hline $22-27$ & Baik \\
\hline $16-21$ & Cukup \\
\hline $9-15$ & Kurang \\
\hline
\end{tabular}

Data kemampuan berpikir kritis siswa dianalisis dengan persentase kriteria kemampuan berpikir kritis siswa dengan rumus yaitu:

$\mathrm{P}=\frac{\sum X}{N} \times 100 \%$

(Sudijono, 2014).

Keterangan:

$\mathrm{P} \quad=$ Angka persentase

$\Sigma \mathrm{x} \quad=$ Jumlah seluruh nilai siswa

$\mathrm{N} \quad=$ Jumlah seluruh siswa

Hasil persentase berpikir kritis siswa selanjutnya dikategorikan berdasarkan Tabel 2.

Tabel 2. Kriteria Berpikir kritis

\begin{tabular}{ll}
\hline Persentase & Kriteria \\
\hline $81 \%-100 \%$ & Kritis Sekali \\
$66 \%-80 \%$ & Kritis \\
$56 \%-65 \%$ & Cukup Kritis \\
$41 \%-55 \%$ & Kurang Kritis \\
$0-40 \%$ & Tidak kritis \\
\hline
\end{tabular}




\section{HASIL DAN PEMBAHASAN}

Berdasarkan hasil penelitian yang telah dilakukan, data hasil observasi aktivitas siswa dalam kegiatan pembelajaran dengan model kooperatif tipe think pair share dapat dilihat pada Tabel 3.

Tabel 3. Rerata Skor dan Kategori Aktivitas Siswa

\begin{tabular}{ll}
\hline Siklus & Rerata Skor \\
\hline I & 24,5 \\
II & 27 \\
\hline
\end{tabular}

Data menunjukkan bahwa rerata skor aktivitas siswa mengalami peningkatan dari siklus I ke siklus II. Pada siklus I, rerata skor aktivitas siswa sebesar dengan kategori baik, dan pada siklus II mengalami peningkatan menjadi 27 dengan kategori baik. Hasil penelitian menunjukkan bahwa pada siklus I walaupun aktivitas siswa telah menunjukkan kategori baik, tetapi aktivitas siswa pada tahap pairing dinilai masih belum optimal. Rerata skor aktivitas siswa dalam setiap tahapan pembelajaran dengan model kooperatif tipe think pair share dapat dilihat Tabel 4.

Tabel 4. Rerata Skor Aktivitas Siswa pada Setiap Tahapan Model kooperati (TPS)

\begin{tabular}{lccc}
\hline Tahap & Siklus I & Siklus II & Keterangan \\
\hline Thinking & 12 & 12 & Optimal \\
Pairing & 2 & 3 & Meningkat \\
Sharing & 10,5 & 12 & Meningkat \\
\hline Menurut & Dierich & dalam & Hanafiah dan \\
Suhana (2010) & menyatakan, aktivitas \\
belajar peserta didik dibagi kedalam & dika \\
delapan kelompok, yaitu sebagai berikut: \\
kegiatan visual, lisan, mendengarkan, \\
menulis dan kegiatan metrik. Pada siklus I \\
dan siklus II, di tahap thinking terdapat \\
aspek membagi siswa dalam kelompok \\
kooperatif, ada juga aspek menjelaskan \\
kegiatan kelompok kooperatif. Pada tahap \\
ini guru menjelaskan tujuan pembelajaran \\
menggunakan media power point dan \\
menunjukan indikator berpikir kritis dalam \\
memecahkan masalah serta menggunakan \\
kata-kata yang operasional. Menjelaskan
\end{tabular}

tujuan pembelajaran sangat penting dilakukan agar siswa dapat memahami bahwa apa saja pengetahuan yang perlu dicapai dalam proses pembelajaran. Hal ini selaras dengan pendapat Kosasih (2014), yang menyatakan bahwa menjelaskan tujuan pembelajaran penting dilakukan, karena apabila siswa sudah mengetahui tujuan pembelajaran, siswa akan menjadi lebih terarah dalam proses pembelajaran. Kegiatan Selanjutnya pada aspek mengajukan fenomena melalui video untuk memunculkan masalah yaitu guru mengajukan fenomena untuk memunculkan masalah.

Menyampaikan pembelajaran secara jelas dengan menggunakan media dapat membantu siswa memahami konsep materi yang akan di pelajari hal ini sesuai dengan pendapat Sanaky (2009) dalam Verawati (2012) yakni menggunakan media dapat mempermudah proses pembelajaran di kelas, meningkatkan efisiensi proses pembelajaran, menjaga relevansi antara materi pelajaran dengan tujuan belajar, membantu konsentrasi pembelajar dalam proses pembelajaran. Guru berupaya untuk memberikan motivasi kepada siswa melalui pertanyaan-pertanyaan yang dapat membangkitkan rasa ingin tahu dan antusisme siswa, serta mempertimbangkan dengan baik penggunaan alokasi waktu pembelajaran agar dapat membimbing kegiatan diskusi pada seluruh kelompok.

Pada tahap pairing, kekurangan yang ditemukan yaitu hanya 4 kelompok dari 7 kelompok siswa yang bekerjasama mengumpulkan informasi untuk menyelesaikan LDPD. Hal ini disebabkan oleh upaya guru dalam membimbing kelompok dengan memberikan arahan pada saat siswa mengalami kesulitan dalam mengumpulkan informasi masih belum optimal.

Sedangkan pada tahap Sharing, kekurangan yang ditemukan yaitu masih sebagian kecil kelompok siswa yang terlibat 
aktif untuk melakukan diskusi untuk menyelesaikan LDPD. Hal ini terlihat saat proses pembelajaran yaitu hanya 3 kelompok yang berdiskusi untuk menyelasaikan LDPD tentang pencemaran udara. Sedangkan pada 4 kelompok lainnya, kegiatan diskusi dalam menyelesaikan LDPD hanya didominasi oleh beberapa anggota kelompok yang memiliki kemampuan akademik tinggi, sedangkan anggota kelompok yang kemampuan akademiknya sedang dan rendah belum menunjukkan partisipasinya. Hal ini disebabkan oleh belum optimalnya upaya guru dalam membimbing kegiatan diskusi kelompok. Guru belum membimbing seluruh kelompok dalam berdiskusi untuk menyelesaikan LDPD, hal ini dikarenakan penggunaan waktu pembelajaran yang sudah melebihi alokasi waktu yang telah ditentukan serta belum terbiasanya siswa dengan model pembelajaran kooperatif tipe think pair share, karena selama ini menggunakan model yang berfokus ke pada guru.

Berdasarkan kekurangan-kekurangan yang ditemukan tersebut, guru merencanakan perbaikan untuk meningkatkan aktivitas siswa pada siklus II. Menurut Majid (2014) teknik pembelajaran adalah siasat atau cara yang dilakukan oleh guru dalam melaksanakan kegiatan belajar mengajar untuk dapat memperoleh hasil yang optimal. Kegiatan belajar mengajar merupakan suatu proses interaksi antara anak didik dan guru untuk mengajarkan pengetahuan tentang nilai-nilai dan sikap dalam kegiatan pendidikan di kelas. Upaya guru untuk melakukan perbaikan menyebabkan peningkatan rerata skor aktivitas siswa di siklus II menjadi 27 yaitu dengan kategori baik. Pada siklus II, seluruh siswa sudah terlibat aktif dalam proses pembelajaran. Rerata skor pada tahap pairing mengalami peningkatan menjadi 3 . Hal ini dikarenakan membimbing kelompok dengan memberikan arahan pada saat siswa mengalami kesulitan dalam mengumulkan informasi sudah optimal. Masalah yang disajikan guru dapat memancing rasa ingin tahu siswa untuk belajar sehingga seluruh kelompok siswa antusias memperhatikan penjelasan prosedur kegiatan diskusi oleh guru. Rerata skor pada tahap sharing juga mengalami peningkatan menjadi 12 . Seluruh siswa terlibat aktif dalam kegiatan diskusi kelompok dalam menarik kesimpulan berdasarkan kegiatan pembelajaran yang telah dilakukan. Hal ini terlihat saat proses pembelajaran yaitu seluruh kelompok siswa yang terlibat aktif untuk melakukan diskusi untuk menyelesaikan LDPD. Hal ini disebabkan oleh upaya guru dalam membimbing kegiatan diskusi pada seluruh kelompok telah optimal.

Peningkatan aktivitas siswa diikuti dengan peningkatan kemampuan berpikir kritis siswa. Hal ini didukung oleh pendapat Nur'aini (2016) yang menyatakan bahwa peningkatan aktivitas guru dan aktivitas siswa dengan penerapan model kooperatif tipe think pair share berdampak terhadap peningkatan kemampuan berpikir kritis siswa. Data kemampuan berpikir kritis siswa dapat dilihat pada Tabel 5.

Tabel 5. Persentase Kriteria Kemampuan Berpikir Kritis Siswa

\begin{tabular}{cc}
\hline Siklus & Rerata Skor \\
\hline I & $56,43 \%$ \\
II & $72,50 \%$ \\
\hline
\end{tabular}

Pada siklus I kemampuan berpikir kritis siswa masih berada pada kriteria cukup kritis dengan persentase 56,43\%, masih banyak siswa yang belum mampu mengidentifikasi dengan memberikan penjelasan lanjutan serta menganalisis dengan mengonstruksi argument pada saat mengerjakan soal tes.

Pada siklus II, kemampuan berpkir kritis siswa meningkat, hal ini terlihat dari meningkatnya persentase kemampuan berpikir kritis siswa dengan indikator yaitu 
mengidentifikasi dengan memberikan penjelasan lanjuan, menganalisis dengan mengonstruksi argument, memberikan solusi alternatif (Ennis, 1985 dalam Muhfahroyin, 2009). Meningkatnya persentase kemampuan berpikir kritis siswa menjadi $72,50 \%$ dengan kriteria kritis. Pengertian Berpikir Kritis merupakan salah satu cara yang bisa dipercaya dan bertanggung jawab yang mempengaruhi hidup seseorang yang berpikir kritis. Banyak siswa yang sedang berlatih dengan menulis dan menjawab pertanyaan yang membutuhkan tingkat tinggi akan menjawab dengan lebih baik dalam ujian (Boleng, 2014).

Hal ini dilihat dari banyak siswa yang sudah memberikan penjelasan dengan mengaitkan unsur/data yang diketahui mengenai masalah dengan pengaruhnya terhadap lingkungan serta siswa telah mampu mencari tahu perbandingan informasi untuk memberikan pendapat berdasarkan pengetahuan tersebut. Adapun kemampuan berpikir kritis dapat dikembangkan seperti yang diungkapkan oleh Facione (2000): "The cognitive skills of analysis, interpretation, inference, explanation, evaluation, and of monitoring and correcting one's own reasoning are at the heart of critical thinking. Through practice, and with guidance from a good instructor, we can develop our thinking skills (like our artistic, athletic, or leadership skills) to the extent our natural abilities allow".

Hasil penelitian ini didukung oleh hasil penelitian Nur'aini (2016) yang menyimpulkan bahwa siswa pembelajaran menggunakan model pembelajaran ThinkPair-Share menarik, menyenangkan, memotivasi mereka untuk belajar aktif dan bekerja sama, mudah dimengerti, media yang digunakan menarik sehingga membantu memahami materi dan soal evaluasi dengan tingkatan beripikir kritis sesuai dengan materi yang diajarkan. Hasil penelitian Arpin (2014) menunjukan bahwa penerapan model kooperatif tipe think pair share (TPS) di kelas VIId SMPN 17 Kota Bengkulu pada pembelajaran IPA-Biologi dapat meningkatkan hasil belajar siswa sehingga mencapai kriteria tuntas. Hal ini berbeda ketika proses pembelajaran konvensional yang diketahui lebih dominan pada teacher centered, sehingga daya berpikir siswa tidak berkembang dengan baik. Hal ini sesuai pendapat Asna (2016) yang menyatakan bahwa hasil pembelajaran konvensional mengakibatkan siswa hanya terbatas mengingat konsepkonsep dari materi pelajaran yang disampaikan oleh guru.

\section{PENUTUP}

\section{Simpulan}

Penerapan model pembelajaran kooperatif tipe think pair share dapat meningkatkan aktivitas dan kemampuan berpikir kritis siswa kelas XIPA 3 SMAN 1 Kota Bengkulu pada materi perubahan dan pelestarian lingkungan. Hal ini terlihat dari rerata skor aktivitas siswa yang diperoleh pada siklus I sebesar 24,5 (Baik), dan pada siklus II mengalami peningkatan menjadi 27 (Baik). Peningkatan aktivitas siswa diikuti dengan peningkatan kemampuan berpikir kritis siswa. Hal ini terlihat dari persentase kemampuan berpikir kritis siswa pada siklus I yaitu 56,43\% (Cukup Kritis), dan pada siklus II mengalami peningkatan menjadi72,50\%

\section{Saran}

Berdasarkan hasil penelitian yang telah dilakukan, maka disarankan bagi guru mata pelajaran biologi kelas XIPA3 SMA Negeri 1 Kota Bengkulu dapat menggunakan model Kooperatif Tipe Think pair share sebagai salah satu alternatif dalam pembelajaran untuk diterapkan pada pembelajaran Biologi materi perubahan dan pelestarian lingkungan sebagai salah satu upaya meningkatkan kemampuan berpikir kritis siswa. 


\section{DAFTAR PUSTAKA}

Arifin, Z. 2017. Mengembangkan Instrumen Pengukur Critical Thinking Skills Siswa pada Pembelajaran Matematika Abad 21. Jurnal THEOREMS (The Original Research of Mathematics), (Online), Vol. 1, No. 2, Hal. 92-100, (http://jurnal.unma.ac.id, diakses 5 Februari 2017).

Arpin. 2014. Penerapan Model Kooperatif Tipe Think pair share (TPS) Pada Pembelajaran IPA-Biologi Untuk Meningkatkan Hasil Belajar Siswa Kelas Viid Smpn 17 Kota Bengkulu. Skripsi tidak diterbitkan. Bengkulu: Program Studi Pendidikan Biologi, FKIP Universitas Bengkulu.

Asna, R. H. 2016. Implementasi Strategi Pembelajaran Berbasis Inkuiri dengan Siklus Belajar 5E untuk Meningkatkan Keterampilan Berpikir Kritis. Jurnal Penelitian Pendidikan, (Online), ISSN 1412$565 \mathrm{X}$, Hal. 154-162, (http://ejournal.upi.edu/index.ph p/JER/article/viewFile/3119/2141, diakses 6 Februari 2017).

Astriani, Nia. 2017. Upaya Meningkatakan Kemampuan Berpikir Kritis Siswa Dalam Pembelajaran Matematika Melalui Model Pembelajaran Kooperatif Tipe Think pair share (TPS) Kelas Vii C Smp Negeri 11 Yogyakarta. Program Studi Pendidikan Matematika UniversitasPGRIYogyakarta(http:// repository.upy.ac.id/1554/1/Artik el.pdf diakses 29 November 2017 )

Boleng, D. T. 2014. Pengaruh Model Pembelajaran Cooperative Script Dan Think pair share Terhadap Keterampilan Berpikir Kritis, Sikap Social, Dan Hasil Belajar Kognitif Biologi Siwa Sma Multietnis.
Pendidikan sains 2(2):76-84. (htTPS://media.neliti.com/media/ publications/173157-ID-none.pdf diakses 29 November 2017)

Facione, Peter. 2000. The Disposition Toward Critical Thinking: Its Character, Measurement, and Relationship to Critical Thinking Skill. Santa Clara University. Informal Logic, Vol 20, No. 1, pp: 61-84.

Hanafiah, Nanang. \& Suhana, Cucu. 2010. Konsep Strategi Pembelajaran. Bandung.: PT Refika Aditama.

Kosasih, E. 2014. Strategi Belajar dan Pembelajaran Implementasi Kurikulum 2013 . Bandung: Penerbit Yrma Widya.

Kunandar. 2011. Langkah Mudah Penelitian Tindakan Kelas Sebagai Pengembangan Profesi Guru. Jakarta: PT Rajawali Pers.

Majid, Abdul. 2014. Strategi Pembelajaran. Bandung: PT Remaja Rosdakarya.

Muhfahroyin. 2009. Memberdayakan kemampuan berpikir kritis siswa melalui pembelajaran konstruktivik. Jurnal Pendidikan \& Pembelajaran 16 (1): 8893. (http://journal.um.ac.id/index. php/pendidikan-dan pembelajaran/article/view/2611 diakses 29 November 2017)

Nur 'aini, Fitri ria. 2016. Meningkatkan Keaktifan Dan Berpikir Kritis Siswa Melalui Model Pembelajaran Kooperatif Tipe Think-Pair-Share (TPS) Pada Sub Bab Plantae Kelas Vii A Mts Tribakti Kunjang. Artikel Skripsi Universitas Nusantara PGRI Kediri.(http://simki.unpkediri.ac.id /mahasiswa/file artikel/2016/12.1 $.01 .06 .0016 . p d f$ diakses 29 November 2017)

Susanti, M. N. I. 2010. Statistik Deskriptif dan Induktif. Yogyakarta: Graha Ilmu. 
Diklabio: Jurnal Pendidikan dan Pembelajaran Biologi 3(1): 116- (Mei 2019) e-ISSN 2598-9669

Trianto. 2007. Model-model pembelajaran inovatif berorientasi konstruktivistik. Jakarta :Prestasi Pustaka

Verawati. 2012. Pemanfaatan Media Pembelajaran Elektronik di KalanganGuruSMP(Online).(http:// repository.uksw.edu/bitstream/12 3456789/1831/3/T1_162008060 BAB II.pdf diakses 29 November 2017)

UU No. 20 Tahun 2003 tentang Sistem Pendidikan Nasional (Sisdiknas). 